\title{
Stability of Protein and Ribonucleic Acid in Bacillus stearothermophilus
}

\author{
By T. P. COULTATE, T. K. SUNDARAM* AND J. J. CAZZULO \\ Department of Biochemistry, School of Biological Sciences, \\ University of Leicester, Leicester $\mathrm{LEI}_{7}{ }_{\mathrm{RH}}$
}

(Received I9 June 1975)

\begin{abstract}
SUMMAR Y
The turnover of protein in a prototrophic strain of Bacillus stearothermophilus during exponential growth in a salts medium with glucose or succinate as carbon source was about $4 \% / \mathrm{h}$ and in a richer nutrient broth medium about $23 \% / \mathrm{h}$. Protein degradation under non-growing conditions conformed to a similar pattern. The turnover of RNA (non-messenger) was about $\mathrm{I} \% \mathrm{~h}$ in salts medium and about $9 \% / \mathrm{h}$ in nutrient broth. The turnover of protein and RNA in the thermophile is thus moderate rather than massive. This conclusion was confirmed by measurement of the decay of a specific enzyme, isocitrate lyase, in the prototroph and of the overall protein turnover in a non-prototrophic strain of $B$. stearothermophilus. The half-lives of a number of enzyme systems in intact cells of the prototrophic thermophile at its optimum growth temperature showed some variation but indicated a significant rate of inactivation. Such decay of protein in vivo apparently accounts for the moderate protein turnover observed during growth.
\end{abstract}

\section{INTRODUCTION}

The rate of turnover of proteins, and also of nucleic acids (other than mRNA), is very low (less than $\mathrm{I} \% / \mathrm{h}$ ) in mesophilic bacteria during exponential growth and somewhat higher (up to $5 \% / \mathrm{h}$ ) under non-growing conditions (Mandelstam, I960; Halvorson, 1962). Protein turnover in the absence of growth appears to occur in these organisms in response to conditions in which synthesis of new proteins takes place in nutritionally deprived environments, such as in sporulation (Mandelstam \& Waites, 1968) and the intermediate lag phase of diauxic growth (Halvorson, 1962). A different function for protein turnover in thermophilic micro-organisms was envisaged by Allen's (1953) hypothesis that thermophiles compensate for the breakdown of macromolecules, particularly proteins, at their high growth temperatures by rapid resynthesis. Although this theory has now been overshadowed by the finding that thermophile proteins are invariably more thermostable than their mesophilic counterparts, there is apparently no agreement on the question of the extent of protein turnover in thermophilic organisms (Goldberg \& Dice, 1974). Thus Bubela \& Holdsworth (1966) reported exceedingly rapid protein turnover in Bacillus stearothermophilus, suggesting that this result lent support to Allen's idea; Epstein \& Grossowicz (1969b), on the other hand, observed that the rate of protein turnover in their prototrophic strain of $B$. stearothermophilus was similar to that found in mesophiles.

We examined the degradation of macromolecules, particularly proteins, in B. stearo-

* Present address: Department of Biochemistry, University of Manchester Institute of Science and Technology, Sackville Street, Manchester M60 IQD. 
thermophilus under a variety of conditions, and also the thermal inactivation of a number of enzyme systems within the bacterium. The results suggest that a moderate degree of protein turnover occurs in this organism even during growth.

\section{METHODS}

Organisms. A prototrophic thermophile, Bacillus stearothermophilus var. nondiastaticus, described by Epstein \& Grossowicz (I969a), was used in most experiments. A culture of this organism was donated by Professor N. Grossowicz, Hebrew University-Hadassah Medical School, Jerusalem, Israel. A more typical strain of B. stearothermophilus (NCIB8923; ATCCI 2980), non-prototrophic and requiring a more complex medium for growth, was employed to test the general applicability of some of the results obtained with the prototrophic strain. Both strains were grown at $55^{\circ} \mathrm{C}$ for $24 \mathrm{~h}$ on nutrient agar (Oxoid) slopes, which were then stored at $4{ }^{\circ} \mathrm{C}$.

Media and growth conditions. The salts medium used for growing the prototrophic strain was that described by Epstein \& Grossowicz (1969a), supplemented with D-biotin at a level of $50 \mu \mathrm{g} / \mathrm{l}$ (Sundaram, 1973) and the appropriate carbon source (D-glucose, sodium succinate or sodium acetate, usually at $50 \mathrm{~mm}$ ). Nutrient broth (Oxoid), sometimes supplemented with $10 \mathrm{~mm}$-sodium succinate, was also used. The non-prototrophic strain was grown in nutrient broth supplemented with $30 \mathrm{mM}$ D-glucose. The organisms were grown at $55^{\circ} \mathrm{C}$ in a gyratory shaker (New Brunswick Scientific Co., model G25); when accurate temperature control was essential, a water bath shaker (New Brunswick Scientific Co., model $\mathrm{G}_{76}$ ) was used.

Chemicals. $\mathrm{L}-\left[\mathrm{I}-{ }^{14} \mathrm{C}\right]$ leucine of specific radioactivity $50 \mathrm{mCi} / \mathrm{mmol}$ and $\left[2-{ }^{14} \mathrm{C}\right]$ uracil of specific radioactivity $40.4 \mathrm{mCi} / \mathrm{mmol}$ were obtained from the Radiochemical Centre, Amersham, Buckinghamshire. Biochemical reagents were purchased from Sigma or Boehringer Corporation Ltd, London. All other chemicals were obtained from various commercial sources at the highest purity available.

Turnover during growth. The method for the study of protein turnover was based on that outlined by Mandelstam (1960). The organism was grown for several generations in the appropriate medium supplemented with $\mathrm{L}-\left[\mathrm{I}-{ }^{14} \mathrm{C}\right]$ leucine in order to ensure general labelling of the cellular proteins with the radioactive amino acid. While still in the exponential phase, the culture was harvested under aseptic conditions by centrifugation at $25^{\circ} \mathrm{C}$. The cells were washed with medium containing unlabelled L-leucine ( $\mathrm{I} \mathrm{mg} / \mathrm{ml}$ ) and inoculated into fresh growth medium also supplemented with non-radioactive leucine ( $\mathrm{I} \mathrm{mg} / \mathrm{ml}$ ). This culture was incubated with shaking at $55{ }^{\circ} \mathrm{C}$ and growth was monitored by measuring the $E_{680}$ of samples withdrawn at appropriate times. The amount of radioactivity that remained in undegraded protein was determined at suitable time intervals during growth as follows. Portions ( $\mathrm{I} \mathrm{ml}$ ) of the culture, usually in triplicate, were taken into $\mathrm{I} \mathrm{ml}$ of $10 \%(\mathrm{w} / \mathrm{v})$ trichloroacetic acid at $0^{\circ} \mathrm{C}$. After standing for at least $30 \mathrm{~min}$, the precipitate was collected on glass fibre filters (Whatman GF/C, diameter $25 \mathrm{~mm}$ ) and washed several times with ice-cold $5 \%(\mathrm{w} / \mathrm{v})$ trichloroacetic acid. The last traces of water and trichloroacetic acid were removed by washing the filter with acetone. The filters were dried and the radioactivity in the precipitates was measured using a toluene-based scintillation fluid consisting of $0.5 \%(\mathrm{w} / \mathrm{v}) \quad 2,5$-diphenyloxazole $+0.03 \%(\mathrm{w} / \mathrm{v})$ I,4-bis[2(4-methyl-5-phenyl-oxazolyl)]benzene in toluene, in a Packard 4000 scintillation spectrometer. From these data the half-life $\left(t_{\frac{1}{2}}\right)$ of the cellular proteins during growth was obtained. The turnover time $\left(t_{t}\right)$ of the proteins was calculated from the relationship: $t_{\mathrm{t}}=t_{\frac{1}{2}} / \ln 2$ (Tarver, 1954). The turnover 
of RNA was determined in an essentially similar manner, with $\left[2-{ }^{14} \mathrm{C}\right]$ uracil and unlabelled uracil replacing $\left[{ }^{14} \mathrm{C}\right]$ leucine and unlabelled leucine, respectively.

Protein breakdown under non-growing conditions. The organism was grown for several generations in medium containing $\left[{ }^{14} \mathrm{C}\right]$ leucine. Chloramphenicol $(250 \mu \mathrm{g} / \mathrm{ml})$ was then added to stop growth and further incorporation of radioactive leucine into protein (Cazzulo, Sundaram \& Kornberg, 1969). The radioactive protein remaining undegraded during continued incubation was measured at suitable times as described above.

Decay of isocitrate lyase (EC. 4.I.3.I) during growth. The prototrophic strain of $B$. stearothermophilus was grown for several generations in salts medium with 50 mM-sodium acetate as carbon source. While the culture was still in the exponential phase, the cells were harvested by centrifugation at $25^{\circ} \mathrm{C}$ and transferred into fresh salts medium containing $25 \mathrm{~mm}$-glucose as carbon source and allowed to grow at $55^{\circ} \mathrm{C}$. Under these conditions the further formation of isocitrate lyase was repressed. The rate at which the enzyme that had been formed during growth on acetate decayed during subsequent growth on glucose was determined as follows. At appropriate times, samples $(80 \mathrm{ml})$ of the culture were withdrawn and the extent of growth was determined by measuring the $E_{680}$. The cells were collected by centrifugation at $5{ }^{\circ} \mathrm{C}$, washed once with $50 \mathrm{~mm}$-tris (hydroxy-

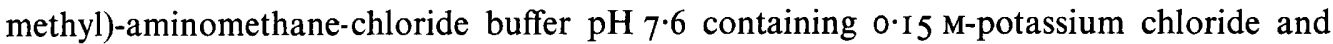
I mM-EDTA, and suspended in the same buffer mixture to a final volume of $4 \mathrm{ml}$. Lysozyme (EC. 3.2.1.17) $(750 \mu \mathrm{g})$ was added and the mixture was incubated at $37^{\circ} \mathrm{C}$ for $30 \mathrm{~min}$. EDTA ( $\mathrm{I} \mathrm{mM}$ ) was then added to a final volume of $8 \mathrm{ml}$ and the mixture centrifuged at $25000 \mathrm{~g}$ for $30 \mathrm{~min}$ at $4{ }^{\circ} \mathrm{C}$. The supernatant fraction (cell-free extract) was assayed for protein by the method of Lowry et al. (195I) and for isocitrate lyase according to the procedure described by Kornberg (1965).

Stability of enzyme systems in vivo. The prototrophic strain of B. stearothermophilus was grown at $55^{\circ} \mathrm{C}$ to late exponential phase (extinction of 0.8 at $680 \mathrm{~nm}$ ) in salts medium containing $50 \mathrm{~mm}$-sodium acetate. Chloramphenicol $(250 \mu \mathrm{g} / \mathrm{ml})$ was added to stop further growth, and incubation was continued at $55{ }^{\circ} \mathrm{C}$ with shaking as before. At suitable times, samples were withdrawn, their $E_{680}$ was measured, and the cells were harvested by centrifugation. Cell-free extracts were prepared by lysozyme digestion as described above. The extracts were assayed for isocitrate lyase (Kornberg, I965), pyruvate carboxylase (EC. 6.4.I.I) (Cazzulo, Sundaram \& Kornberg, 1970), malate dehydrogenase (EC. I.I.I.37) (Ochoa, 1955), isocitrate dehydrogenase (EC. I.I.I.42) (Self \& Weitzman, I970) and pyruvate kinase (EC. 2.I.7.40) (Bucher \& Pfleiderer, 1955). In similar, separate experiments, in which the carbon source was either glucose or acetate, samples were withdrawn at suitable times after chloramphenicol addition and diluted with fresh medium. The rates of oxidation of glucose or acetate by the diluted cultures were determined by measuring their oxygen uptake with an oxygen electrode (Rank Bros.) as described by Coultate \& Sundaram (I975).

\section{RESULTS}

\section{Protein and RNA turnover during growth}

The rates of increase in cell mass and of the degradation of $\left[{ }^{14} \mathrm{C}\right]$ leucine-labelled proteins during the growth of prototrophic $B$. stearothermophilus in two different media at $55^{\circ} \mathrm{C}$ are shown in Fig. I. On the salts-glucose medium, $t_{\mathrm{t}}$ (calculated from the rate of breakdown of the radioactive proteins) was $23.5 \mathrm{~h}$, representing a protein turnover rate of $4.3 \% / \mathrm{h}$. On the richer nutrient broth-succinate medium, turnover was appreciably faster: $t_{\mathrm{t}}$ was $4.4 \mathrm{~h}$, corresponding to a turnover rate of $23 \% / \mathrm{h}$. Protein turnover in a salts- 


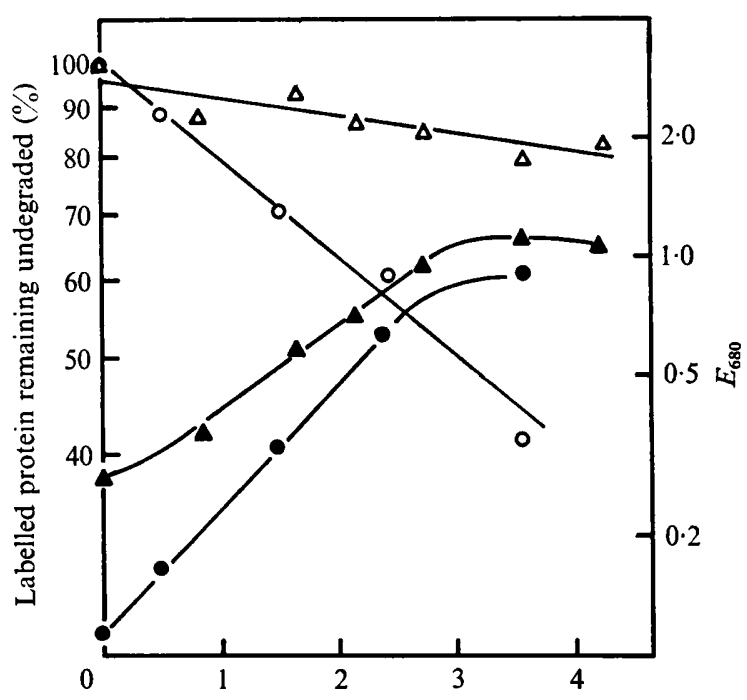

Time after transfer to unlabelled medium (h)

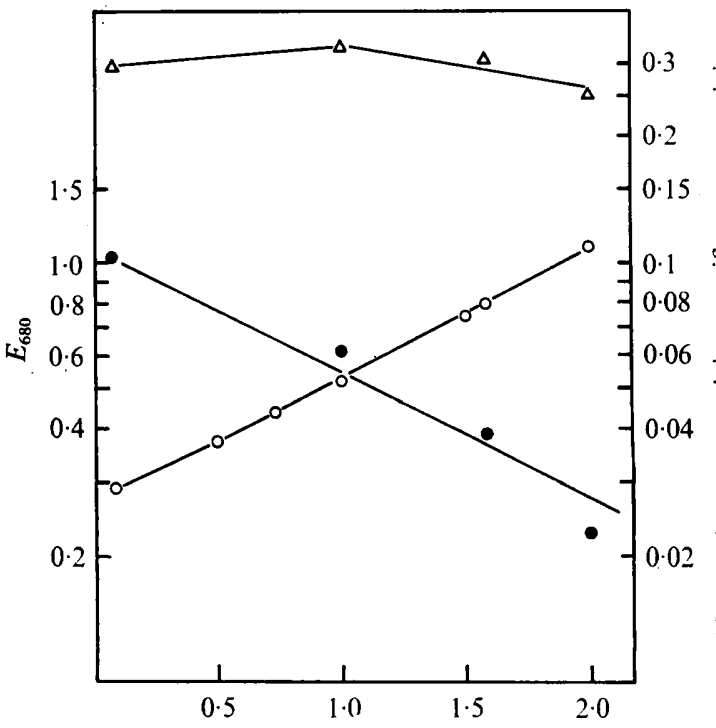

Time after transfer to salts-glucose medium (h?

Fig. I

Fig. I. Protein turnover during growth of $B$. stearothermophilus. The prototrophic strain prelabelled with $\mathbf{L}-\left[\mathrm{I}^{-14} \mathrm{C}\right]$ leucine was grown in salts-glucose (triangles) or nutrient broth-succinate (circles) medium supplemented with non-radioactive leucine. Growth (closed symbols) and radioactive protein remaining undegraded (open symbols) were determined as described in the text. Fig. 2. Decay of isocitrate lyase during growth of prototrophic B. stearothermophilus. Cells pregrown in salts-acetate medium were transferred to a salts-glucose medium. Growth $(O)$ and isocitrate lyase activity of cell-free extracts were determined as described in the text. One unit of isocitrate lyase catalyses the cleavage of $1 \mu \mathrm{mol}$ isocitrate/min; specific enzyme activity (O) is expressed as units of enzyme/mg protein in the cell-free extract. Total enzyme activity in cells $(\triangle)$ is represented by specific enzyme activity $\times E_{680}$. All specific activity values are corrected for the very low level of isocitrate lyase activity in glucose-grown cells (about $\mathrm{I} \cdot 6 \%$ of the activity in acetate-grown cells).

\section{Table I. Turnover of protein and RNA during growth of B. stearothermophilus}

Turnover times were calculated from the rates at which protein and RNA lost their radioactive label during exponential growth.

$\begin{array}{llll}\text { Organism } & \text { Growth medium } & \text { Protein } & \text { RNA } \\ \text { B. stearothermophilus (prototrophic) } & \begin{array}{l}\text { Salts-succinate } \\ \text { Salts-glucose }\end{array} & 39 & 85 \\ \text { B. stearothermophilus } \text { (non-prototrophic) } & \begin{array}{l}\text { Nutrient broth } \\ \text { Nutrient broth- } \\ \text { glucose }\end{array} & \text { I4 } & \text { I0.5 }\end{array}$

succinate medium was similar to that in the salts-glucose medium (Table I). For the non-prototrophic $B$. stearothermophilus, $t_{\mathrm{t}}$ was $\mathrm{I} 4 \mathrm{~h}$ in nutrient broth-glucose medium, the turnover rate being $7 \% / \mathrm{h}$ (Table $\mathrm{I}$ ). All these rates were observed over a period during which there was a 3- to Io-fold increase in cell mass (see Fig. I). Table I also presents the turnover times for RNA during the growth of prototrophic B. stearothermophilus in salts-succinate medium and in nutrient broth. The turnover rate was about $\mathrm{I} \% / \mathrm{h}$ in the salts medium and about $9 \% / \mathrm{h}$ in broth during a period in which the pre-labelled cells were 


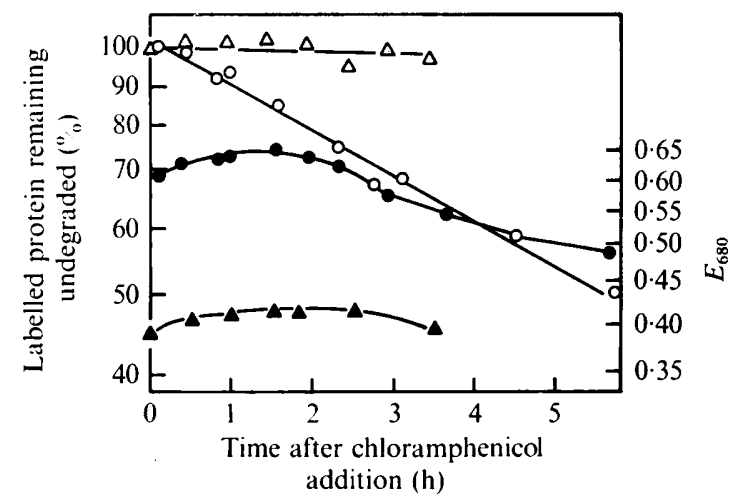

Fig. 3. Protein breakdown in non-growing B. stearothermophilus. Cultures of the prototrophic strain growing in salts-succinate (triangles) or nutrient broth-succinate (circles) medium in the presence of $\left[\mathrm{I}-{ }^{14} \mathrm{C}\right]$ leucine were treated with chloramphenicol $(250 \mu \mathrm{g} / \mathrm{ml})$ at zero time. Radioactive protein remaining undegraded in the cultures (open symbols) was determined as described in the text. Closed symbols represent $E_{680}$.

growing exponentially and multiplied over 3 -fold in medium containing non-radioactive uracil. The rates may therefore be assumed to apply to the more stable RNA species, rRNA and tRNA, rather than to unstable mRNA. It appears, therefore, that during the growth of thermophiles there is a moderate, rather than a massive, turnover of proteins that is faster than that generally observed in growing mesophilic bacteria.

To confirm this point the fate of an enzyme, isocitrate lyase, produced by the prototrophic thermophile when acetate was the sole carbon source, was examined during subsequent growth of the bacterium in a salts-glucose medium. When glucose is available, isocitrate lyase has no physiological function and its synthesis is repressed; the specific enzyme activity in cells grown on glucose is less than $2 \%$ of that in cells grown in a saltsacetate medium. After transfer from salts-acetate to salts-glucose medium, the cells lost the total enzyme activity fairly slowly; the specific enzyme activity declined much faster, as expected, during growth under the repressive conditions (Fig. 2).

\section{Protein breakdown in non-growing cells}

Figure 3 shows the course of degradation of $\left[{ }^{14} \mathrm{C}\right]$ leucine-labelled proteins in prototrophic B. stearothermophilus after the addition of chloramphenicol, which prevented further growth and also the reincorporation into proteins of $\left[{ }^{14} \mathrm{C}\right]$ leucine released as a result of protein breakdown. The half-life of the proteins in a salts-succinate or salts-acetate culture was over $50 \mathrm{~h}$ and that in nutrient broth-succinate culture $5.4 \mathrm{~h}$, measured during a period of about $3 \mathrm{~h}$ following chloramphenicol addition, while the cell density remained relatively steady. These half-lives are equivalent to turnover rates of approximately $\mathrm{I}$ and $13 \% / \mathrm{h}$, respectively.

\section{Enzyme stability in the intact thermophile cell}

The rather similar rates of protein degradation observed in growing and chloramphenicoltreated cells suggested that information on the stability of individual enzymes under physiological conditions in the thermophile might be obtained from a study of their rates of inactivation following chloramphenicol treatment. All the enzymes examined decayed at low, but significant, rates (Fig. 4). From the course of decay in the $3 \mathrm{~h}$ after chloramphenicol treatment (a period during which the cell density of the culture changed only 


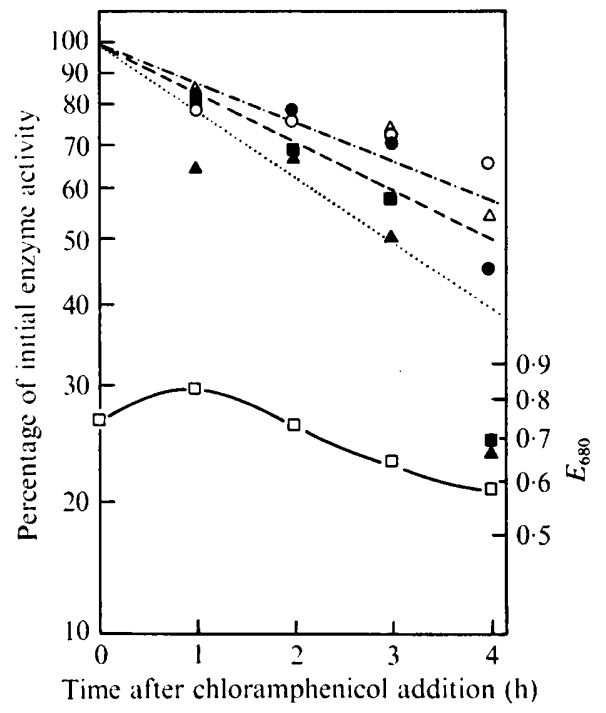

Fig. 4

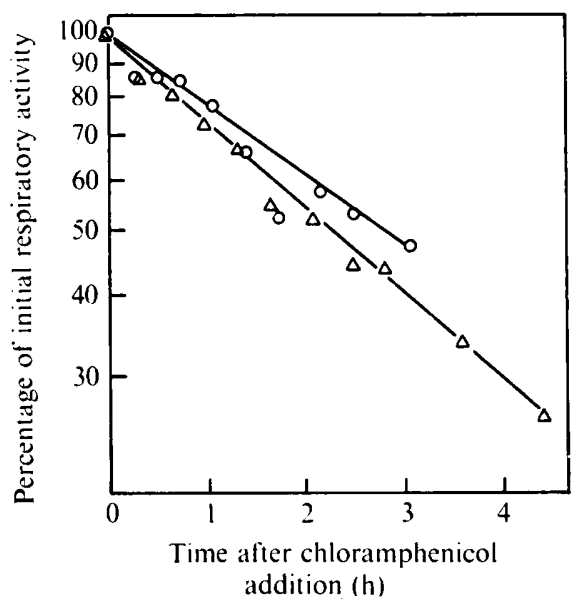

Fig. 5

Fig. 4. Stability of enzymes at $55^{\circ} \mathrm{C}$ in prototrophic $B$. stearothermophilus. Experimental details are given in the text. The activities of the various enzymes $/ \mathrm{ml}$ culture were determined; the activity at the time of chloramphenicol addition is always taken as $100 \% . \square, E_{680} ; \boldsymbol{\Delta}$, isocitrate lyase; 0 , isocitrate dehydrogenase; $\Delta$, malate dehydrogenase; $\boldsymbol{\square}$, pyruvate carboxylase; $\bigcirc$, pyruvate kinase. Theoretical lines of exponential decay, representing half-lives of $3(\ldots), 4(--)$ and 5 (-.-.) $\mathrm{h}$, are shown to provide a means of estimating the rates of decay of the enzymes.

Fig. 5. Stability at $55^{\circ} \mathrm{C}$ of the enzyme systems oxidizing acetate and glucose in prototrophic $B$. stearothermophilus. Experimental details are given in the text. The activities of the enzyme systems oxidizing acetate $(O)$ and glucose $(\triangle)$ were determined, using an oxygen electrode, in samples of cultures withdrawn at appropriate times after chloramphenicol addition.

slightly), the half-lives of isocitrate lyase and pyruvate carboxylase were approximately $4 \mathrm{~h}$; isocitrate dehydrogenase, malate dehydrogenase and pyruvate kinase were appreciably more stable with half-lives of over $6 \mathrm{~h}$. The thermostability of the multi-component respiratory system of the thermophile was examined similarly, with glucose or acetate as substrate. The respiratory activity on either substrate decayed with a half-life of about $2 \cdot 5$ h (Fig. 5).

\section{DISCUSSION}

The observation that almost all the thermophile proteins that have been examined are more thermostable in vitro than their mesophilic counterparts (Amelunxen \& Lins, I968) has been taken as evidence against Allen's high turnover theory. The validity of such an interpretation is questionable, since information concerning the stability of proteins inside the cell at the growth temperature of any thermophile is meagre. The only two studies on protein turnover in thermophilic bacteria have produced divergent conclusions. Bubela \& Holdsworth (I966) reported a turnover time of $\mathrm{I}$ to $2 \mathrm{~min}$ in B. stearothermophilus and suggested that the exceedingly rapid turnover ( 30 to 60 times an hour) that this result indicated lent support to Allen's hypothesis. However, in their experiments thick suspensions of resting cells were used, and these were exposed to radioactive amino acid for only $5 \mathrm{~min}$. Under these conditions homogeneous labelling of the cellular proteins could not have been achieved. Moreover, the subsequent loss of label from protein was followed for only $2 \mathrm{~min}$. The physiological significance of their results is therefore difficult 
to establish. It is noteworthy that, using the same experimental technique, these workers observed a protein turnover rate in Escherichia coli of $250 \% / \mathrm{h}$, a value more than two orders of magnitude greater than the values reported by other laboratories (Mandelstam, I960). The second study of protein turnover, that by Epstein \& Grossowicz (I969 $b$ ), indicated the protein turnover rate in thermophiles to be similar to that generally found in mesophiles. The thermophile used by these workers was the same as the prototrophic strain we used.

The present investigation, in which two strains of $B$. stearothermophilus were used, indicates a low but significant rate of protein turnover in growing thermophiles. The more detailed studies with the prototrophic strain suggest that the turnover rate may be affected by the nature of the culture medium. It is very unlikely that the observed difference between the cultures in salts medium and nutrient broth could be due to a slower exchange in the former between the leucine in the intracellular pool and that in the growth medium. It is generally accepted (Pine, 1972) that in bacteria the rate of this exchange is too fast seriously to affect turnover measurements. The turnover of RNA, other than mRNA, appears to be slower, consistent with its greater thermostability as compared with protein. The moderate turnover rate we observed does not remotely approach the rate implied by Allen (1953) and purportedly supported by the work of Bubela \& Holdsworth (1966). Even the highest turnover rate we observed means that the thermophile degrades about $20 \%$ of its proteins in the course of doubling its protein content during exponential growth; in a salts medium the amount degraded is less than $4 \%$. Further support for this conclusion is provided by the molar growth yield (Coultate \& Sundaram, 1975) of the prototrophic thermophile. The growth yield at $55^{\circ} \mathrm{C}$ on glucose or succinate as the sole carbon source, although lower than that at lower temperatures, is not very much different from the yield reported for mesophiles at their optimum growth temperatures; a massive turnover would be expected to reduce the yield drastically.

Although the overall protein turnover is not high, it is possible that some individual proteins could be turned over quite rapidly. In mammalian systems, where overall protein turnover is rapid relative to the growth rate, individual enzymes may vary widely in their degradation rates (Schimke, 1969). Likewise, different enzymes decay at different rates in the thermophile (Figs. 4 and 5). The membrane-bound respiratory system is considerably more labile than the other enzymes examined. The multicomponent nature of this system and its association with the membrane, necessitating the maintenance of structural integrity for respiratory activity, may be responsible for this effect. Brock (I967) pointed out that the membrane might be a particularly sensitive and vulnerable target in the thermal death of living organisms. It is probable that in the evolution of thermophiles, the balancing of the two requirements of thermostability and catalytic efficiency, possibly mutually conflicting, was a key factor. On this basis, proteins of different thermostabilities must be expected in thermophiles, and no single mechanism underlying the stability of all proteins in these organisms may be found. The finding that a number of enzymes decay at an appreciable rate in the thermophile cell at the optimum growth temperature $\left(55^{\circ} \mathrm{C}\right.$ for the prototroph) suggests that the turnover observed is a mechanism essential for disposing of the denatured proteins.

Our results emphasize that the stability of thermophile proteins determined under arbitrarily chosen conditions in vitro could be different from their stability in vivo. For instance, pyruvate carboxylase from the prototrophic B. stearothermophilus has a half-life of only about $20 \mathrm{~min}$ at $55{ }^{\circ} \mathrm{C}$ in vitro in phosphate buffer $\mathrm{pH} 7$. However, it can be stabilized considerably (like the apoenzyme) by its allosteric effectors, acetyl-CoA and 
L-aspartate, metabolites which must be present in vivo (Cazzulo et al., 1970; Sundaram, Cazzulo \& Kornberg, 1971). Another enzyme, isocitrate lyase, from the same organism is stabilized in vitro by a moderately high concentration of salt (Griffiths \& Sundaram, 1973). Stabilization in the intracellular milieu could thus be a physiologically important factor, complementing the innate stability of thermophile enzymes.

We are grateful to Professor H. L. Kornberg for valuable discussions, to Miss Susan N. Dilks for skilful technical assistance, to the Science Research Council, Great Britain for a postgraduate studentship awarded to T.P.C. and to the Consejo Nacional de Investigaciones Cientificas y Tecnicas (Republica Argentina) for a postdoctoral fellowship awarded to J.J.C. Some of the results presented here formed part of T.P.C.'s doctoral thesis submitted to the University of Leicester.

\section{REFERENCES}

Allen, M. B. (1953). The thermophilic aerobic sporeforming bacteria. Bacteriological Reviews 24, 289308.

AmelunXen, R. \& Lins, M. (1968). Comparative thermostability of enzymes from Bacillus stearothermophilus and Bacillus cereus. Archives of Biochemistry and Biophysics 125, 765-769.

Brock, T. D. (1967). Life at high temperatures. Science, New York 158, $1012-1019$.

Bubela, B. \& Holdsworth, E. S. (I966). Amino acid uptake, protein and nucleic acid synthesis and turnover in Bacillus stearothermophilus. Biochimica et biophysica acta 123, 364-375.

Bucher, T. \& Pfleiderer, G. (1955). Pyruvate kinase from muscle. Methods in Enzymology 1, 435-440.

Cazzulo, J. J., Sundaram, T. K. \& KornberG, H. L. (I969). Regulation of pyruvate carboxylase formation from the apoenzyme and biotin in a thermophilic Bacillus. Nature, London 223, I $137-1$ I 38.

Cazzulo, J. J., Sundaram, T. K. \& Kornberg, H. L. (1970). Properties and regulation of pyruvate carboxylase from Bacillus stearothermophilus. Proceedings of the Royal Society B I76, I-I9.

Coultate, T. P. \& Sundaram, T. K. (1975). Energetics of Bacillus stearothermophilus growth: molar growth yield and temperature effects on growth efficiency. Journal of Bacteriology 121, 55-64.

Epstein, I. \& Grossowicz, N. (1969a). Prototrophic thermophilic bacillus. Isolation, properties and kinetics of growth. Journal of Bacteriology 99, 414-417.

Epstein, I. \& GrossowiCz, N. (I969b). Intracellular protein breakdown in a thermophile. Journal of Bacteriology 99, 418-42I.

GolDBERG, A. L. \& DiCE, J. F. (1974). Intracellular protein degradation in mammalian and bacterial cells. Annual Review of Biochemistry 43, 835-869.

Griffiths, M. W. \& Sundaram, T. K. (1973). Isocitrate lyase from a thermophilic Bacillus: effect of salts on enzyme activity. Journal of Bacteriology 116, $1160-1169$.

Halvorson, H. O. (1962). The function and control of intracellular protein turnover in microorganisms. In Amino Acid Pools, pp. 646-654. Edited by J. T. Holden. Amsterdam: Elsevier.

KorNBerG, H. L. (1965). Control of biosynthesis from $\mathrm{C}_{2}$ compounds. In Mecanismes de regulation des activités cellulaires chez les microorganismes. Colloques Internationaux du Centre National de la Recherche Scientifique No. 124, pp. 193-207.

Lowry, O. H., Rosebrough, N. J., Farr, A. L. \& Randall, R. J. (195I). Protein measurement with the Folin phenol reagent. Journal of Biological Chemistry 193, 265-275.

MANDELSTAM, J. (1960). The intracellular turnover of protein and nucleic acids and its role in biochemical differentiation. Bacteriological Reviews 24, 289-308.

Mandelstam, J. \& Waites, W. M. (1968). Sporulation in Bacillus subtilis. The role of exoprotease. Biochemical Journal 109, 793-80I.

OCHOA, S. (1955). Malic dehydrogenase from pig heart. Methods in Enzymology 1, 735-739.

PINE, M. J. (1972). Turnover of intracellular proteins. Annual Review of Microbiology 26, 103-I 26.

SCHIMKE, R. T. (I969). On the roles of synthesis and degradation in regulation of enzyme levels in mammalian tissues. In Current Topics in Cellular Regulation, vol. I, pp. 77-124. Edited by B. L. Horecker and E. R. Stadtman. New York and London: Academic Press.

Self, C. H. \& Weitzman, P. D. J. (1970). Separation of isoenzymes by zonal centrifugation. Nature, London 225, 644-645.

SUNDARAM, T. K. (1973). Physiological role of pyruvate carboxylase in a thermophilic bacillus. Journal of Bacteriology $113,549-557$.

Sundaram, T. K., Cazzulo, J. J. \& Kornberg, H. L. (197I). Synthesis of pyruvate carboxylase from its apoenzyme and (+)-biotin in Bacillus stearothermophilus. Mechanism and control of the reaction. Biochemical Journal 122, 663-669.

TArver, H. (1954). Peptide and protein synthesis: protein turnover. In The Proteins, vol. 2B, pp. II991296. Edited by H. Neurath and K. C. Bailey. New York: Academic Press. 